Acta Universitatis Wratislaviensis No 4053

Studia Linguistica XL Wrocław 2021

https://doi.org/10.19195/0137-1169.40.1

OLGA BARABASZ-REWAK

ORCID: 0000-0001-5418-3947

Uniwersytet Wrocławski, Польща

\title{
Нариси мовного образу ПРАВЕДНОГО в українських текстах Псалтиря (переклад Івана Огієнка)
}

Вивчення активної ролі мови у зв'язку з позалінгвальними факторами в процесі категоризації та структуризації дійсності стало підгрунтям сучасної когнітивної етнолінгвістики, яка трактує мову як постійне діяння. У пропонованому дослідженні спираємося на близьке нам розуміння терміна „когнітивна етнолінгвістика" та відповідну методологію, які притаманні люблінській етнолінгвістичній школі ${ }^{1}$, а також використовуємо дослідження українських дослідників різних періодів - О. Потебні, В. Кононенка, В. Жайворонка, Р. Кіся, О. Сімович, О. Федик, Т. Космеди, П. Мацькова, І. Голубовської, Н. Данилюк та ін. Розширена відповідь на питання щодо назви (назв) цієї дисципліни та обгрунтування вибору терміна містяться в публікаціях найвпливовішого представника школи С. Бартмінського (Bartmiński 2009:7-8; Bartmiński 2016:20-23). Оскільки „етнолінгвістичні дослідження прямують до вияву та опису спільнотної, передовсім національної, тотожності" (Bartmiński/Chlebda 2013:70), неодмінним компонентом етнолінгвістичних наукових розробок є концепція мовної картини світу (МКС). Найзагальніше визначення МКС - це „різним чином звербалізована дійсність, яка міститься в мові та складає сукупність суджень про світ" (Bartmiński 2006:12). Це можуть бути судження, закріплені в граматиці, лексиці, паре-

\footnotetext{
1 Першими й основними підвалинами люблінської етнолінгвістики стали аналіз мови фольклору, дослідження слов'янської народної культури (етимологічні й діалектологічні розробки представників московської етнолінгвістичної школи), філософія німецьких учених Й. Гердера та В. фон Гумбольдта щодо образу (чи картини) світу, погляди американських релятивістів Ф. Боаса, Е. Сепіра, Б. Уорфа - й пізніше, дослідження А. Вєжбіцкої та представників когнітивної лінгвістики (зокрема В. Еванс, Б. Бергена, Й. Зінкена) (пор. Bartmiński 2016).
} 
мійних текстах, а також у позамовних (етнографічних) даних. Відтак концепція Ф. Боаса про те, що кожна мова виражає лише вибрану частину поняття (Boas 1966:39), яке міститься у свідомості, у люблінській теорії МКС набуває вигляду твердження про те, що маємо справу не зі загальними і вербалізованими поняттями (хоча їхнє існування не заперечується), а з поняттями, закодованими власне в кожній конкретній мові - культурними концептами (або стереотипами) $)^{2}$. Корені цього твердження сягають констатації В. фон Гумбольдта про те, що „кожна мова існує для своїх користувачів у певних межах, поза якими простягається територія іншої мови" (Humboldt 1999:60), відповідно, якщо невід’ємною рисою людини є мова, то картина світу не може існувати поза нею.

Здійснюючи аналіз культурних концептів, у пропонованій статті спираємося на базове поняття когнітивної дефініції, мета якої полягає в ,усвідомленні мовцями способу розуміння предмета, тобто суспільно усталеного і придатного для аналізу за допомогою мови знання про світ, категоризації його явищ, їхньої характеристики і аксіології” (Bartmiński 1988:169). У цьому процесі важливу роль відіграє використання концепції профілювання (пор. Bartmiński 1993 i Niebrzegowska-Bartmińska 2015):

суб'єктивного мовно-поняттєвого аналізу, що полягає у своєрідному формуванні образу предмета. Це конструювання образу здійснюється через виокремлення конкретних аспектів (підкатегорій, фасетів) в рамках певного типу знань і відповідно до вимог визначеного пункту бачення: наприклад, походження, ознаки, вигляд, функції, дії, емоції тощо (Bartmiński/Niebrzegowska 1998:212).

Мовний образ об'єкта обов'язково доповнюється аксіологічним компонентом: оцінювання як обов'язковий чинник виникає зі способу людського світосприйняття. „Чим важливіша роль об'єкта у певній культурі, тим правдоподібніше те, що він і слово, яке його номінує, будуть містити аксіологічний елемент; причому оцінка окремих об’єктів виникає з оцінки ієрархії та її структури, що панує у цій культурі” (Кісь 2002:252). Використання такої дефініції в нашій роботі передбачає реконструкцію (принаймні часткову) культурного концепту (стереотипу) ПРАВЕДНОГО на основі вибраних і фасетно укладених мовних даних (як поодиноких лексем, словосполучень, так і цілих речень, ширших фрагментів) зі словників української мови і текстів Псалтиря перекладу Івана Огієнка, а також екскурсів у сферу вірувань, об-

2 Терміни поняття і концепт об'єднує те, що вони стосуються „ментального кореляту”, який стоїть між лексемою та ії відповідником у реальному світі та який можна було би вписати в структуру мовного знаку, відсилаючи до верхньої точки семантичного трикутника Огдена-Річардсона. Термін МКС містить та відображає всі три елементи семіотичної тріади (пор. Bartmiński/Chlebda 2013). 
рядової практики юдеїв. Ці мовні конструкції експліцитно або імпліцитно 3 реалізують упорядковану сукупність ознак, належачи до семантичної площини мови і посередньо до культури. На потреби цієї роботи використовуємо дещо змінену й адаптовану пропозицію люблінських етнолінгвістів щодо укладання експлікації концепту в блоки згідно зі семантичними категоріями в певній логічній послідовності. 3 огляду на обсяг статті обмежуємося лише кількома аспектами аналізу (парадигматичні відношення, мовні засоби вираження головних атрибутивів і кількісних характеристик, найчастотніших єдностей з іншими фрагментами МКС, які діють в одному часопростоpi), усвідомлюючи обмеженість і частковість результатів цього дослідження.

Одним із фундаментальних концептів, який містять численні народні й наукові тексти кожного народу, є БОГ 4 . Пропонована стаття є частиною 5 ширшого дослідження цілісного мовного образу Бога в українському перекладі Книги Псалмів, здійсненому Іваном Огієнком. У вітчизняних наукових розробках останніх десятиліть саме Біблії належить визначальне місце 3-поміж досліджень релігійного стилю (Д. Степовик, М. Тимошик, Н. Бабич, Т. Мороз, П. Мацьків, Н. Гуйванюк, М. Демський, О. Демська, Н. Сологуб, Л. Ткач, О. Дзера та ін.). Серед перших повних перекладів Святого Письма народною українською мовою знаходимо праці П. Морачевського, П. Куліша, I. Пулюя, I. Нечуя-Левицького, І. Огієнка, I. Хоменка6 ${ }^{6}$ Переклад Івана Огієнка відзначається унікальністю та важливістю в кількох аспектах. Саме його тексти стали: а) першим українським науковим і дослівним перекладом Біблії з оригінальних мов - у цьому контексті можна насмілитися назвати їх т.зв. сакральним каноном українців (після старослов’янського перекладу), б) чи не найкращим слов’янським перекладом узагалі, в) „наріжним каменем розвитку" сучасної української літературної мови та джерельною базою комп’ютерної лексикографічної системи, в якій репрезентовано біблійну лексику й фразеологію для нового академічного „Словника української мови”.

3 Експліцитний спосіб вираження передбачає застосування лексичних та лексико-граматичних засобів, серед котрих найбільшу вагу мають прикметники, іменники, дієслова та структури стверджувальних і заперечних речень. Імпліцитною (лат. implicito - неявний) вважають ту інформацію, яку автор має на увазі, виражає опосередковано, і яку читач виводить зі значень мовних одиниць, які разом у контексті виражають відповідну семантику. Для сприйняття та розуміння змісту повідомлення в адресанта й адресата повинен бути спільний лінгво-когнітивний рівень мовної особистості.

4 У статті застосовано такий графічний принцип: лексеми й інші мовні засоби записуємо курсивом, концепти - ВЕЛИКИМИ літерами, значення подаємо в одинарних 'лапках'.

53 огляду на обмежені можливості публікації в пропонованому тексті взято до уваги вибірку перших двадцяти псалмів джерела „Книга Псалмів”. Застосовано систему скорочень типу Пс 1:6, де 1 - номер псалма, 6 - номер вірша.

6 Детальний історичний огляд українських перекладів Біблії, починаючи від Переяславського Євангелія і до перекладів XXI ст., пропонує О. Дзера у статті „Історія українських перекладів Святого Письма” (2014), де окреслює також відмінність підходів до перекладу і проблему їхньої різночасової рецепції. 
Переклад І. Огієнка мав оригінальну концепцію і наукове підгрунтя. По-перше, митрополит досконало вивчив оригінальні мови Біблії, а також опанував латинську, старослов'янську, польську, німецьку й англійську, щоб зіставити свій переклад із перекладами інших народів. По-друге, він розробив наукові принципи перекладу Біблії й оприлюднив їх 1927 р. у дослідженні „Методологія перекладу Святого Письма та Богослужбових книг на українську мову" [...]: необхідність перекладу Святого Письма сучасною українською мовою [...]; збагачення національної мови, зокрема, через відтворення багатої синоніміки Біблії; неприпустимість уживання в біблійному тексті елементів просторіччя; застосування в перекладі метричного вірша (Дзера 2014:218).

Саме цих принципів бракувало, на думку самого I. Огієнка, у текстах його попередників. Особистою метою автора під час створення власного перекладу було поєднання богословського та навчального аспектів. Тому, беручись до цієї надзвичайно складної роботи, І. Огієнко поставив перед собою два найголовніші завдання: найточніше передати зміст оригіналу, дбаючи передусім про змістову точність цілого ряду багатозначних слів, і забезпечити переклад милозвучною, сучасною літературною мовою. „Перекласти всю Біблію [...] треба такою літературною мовою, яка б стала зразковою бодай на перші 50 літ. Мусимо мати переклад, який став би найкращим підручником вивчення української мови. Без цього нормальний розвій нашої літературної мови не матиме так їй потрібного „каменя наріжного” (Іларіон 1958:13).

Переклад Івана Огієнка відзначається надважливістю ще й у контексті того, що „Біблія як центральний текст європейської культури фактично не має загальнодоступного оригіналу, і саме її національні переклади визначають особливості біблійних мовних картин світу, які, відповідно, зумовлюють своєрідність авторських інтерпретацій” (Дзера 2014:214).

3 огляду на сказане актуальність і новизну пропонованого дослідження вбачаємо у спробі реконструювати вибрані фрагменти культурного концепту ПРАВЕДНИЙ саме в Огієнковому текстовому ареалі Псалтиря. Фасетно укладені мовні дані, які експліцитно та імпліцитно виражають характеристики 'номени', 'основні ознаки' і ‘дії праведного щодо а) Бога, б) грішників’ у світлі концепції профілювання дозволять у результаті прослідкувати багатство й різноаспектність українського наповнення цього концепту, його позитивну аксіологію й розуміння ментального авторського світу Івана Огієнка, непересічної мовної особистості з талантом інтуїтивно відчувати колективний досвід „трансформувати його в такі мовні форми, які і за природою творення, і за характером сприймання (саме в єдності цих двох процесів!) постають як мовно-естетичні знаки національної культури” (Єрмоленко 1999:359).

Згідно 3 „Етимологічним словником української мови”, слово праведний походить від старослов'янського правьдьнъ 'праведний, справедливий', а те - 
від іменника правьда 'правда' (Мельничук 2003:550). На основі словникових статей у „Словнику української мови в 11-ти томах” і „Словарі української мови” Б. Грінченка можна виокремити два основні значення слова праведний: 1) 'той, хто дотримується заповідей, моральних приписів якоїсь релігії; безгрішний' // 'який узгоджується з релігійними приписами, але суперечить гуманним принципам', 2) 'справедливий, правильний' // 'чесний, благородний’ (Білодід 1976:500; Грінченко 1958:398). Джерело „Словники України” online” подає синонімічні засоби вираження назви цього концепту, що відповідають виокремленим значенням лексеми праведний: 1) безгрішний, непогрішний, святий, преподобний, 2) чесний, справедливий, правильний, правий, законний.

У перекладах початкових псалмів І. Огієнка нами виокремлено численні синонімічні номени на позначення особи, яка живе в єдності з Богом. Експліцитне вираження семантики 'безгрішності' реалізують субстантивовані прикметники праведний („Бо Ти, Господи, благословлятимеш праведного”, Пс 5:13); святий („не попустиш Своєму святому побачити тління”, Пс 15:10); побожний, вірний („Спаси мене, Господи, бо нема вже побожного, з-поміж людських синів позникали вже вірні”, Пс 11:2); простосердий („нечестиві натягують лука [...], щоб у темряві до простосердих стріляти”, Пс 10:2); святий, иляхетний (,До святих, які на землі, що шляхетні вони, до них все жадання моє”, Пс 15:3), вбогий („Раду вбогого ганьбите ви”, Пс 13:6), а також прикметники блаженний у короткій формі блажен (,Блажен муж, що за радою несправедливих не ходить, і не стоїть на дорозі грішних, і не сидить на сидінні злоріків”, Пс 1:1); непорочний („І був я із Ним непорочний”, Пс 17:21-25). Друге значення лексеми праведний, 'справедливий, чесний’ експліцитно реалізує іменник доброчинецьь („нема доброчинця”, Пс 13:1). Імпліцитно функцію номенів виконують описові конструкції зі семантикою 'праведність': Ім’я Твоє знають; ті, хто шукає Тебе („І на Тебе надіятись будуть усі, що Ім’я Твоє знають, бо не кинув Ти, Господи, тих, хто шукає Тебе", Пс 9:11), чисті серцем („Щит мій у Бозі, Який чистих серцем спасає”, Пс 7:11), хто надію на Тебе складають („всі, хто надію на Тебе складають”, Пс 5:12), хто вдається до Тебе („Спасителю тих, хто вдається до Тебе”, Пс 16:7).

Словом-символом праведного у біблійному контексті є іменник дерево („І він буде, як дерево, над водним потоком посаджене, що родить свій плід своєдчасно, і що листя не в'яне його, і все, що він чинить, щаститься йому!", Пс 1:3). Використання цього іменника на позначення особи, яка перебуває в близьких стосунках із Богом, зумовлене юдейським світосприйняттям, де дерево означало „Божі насадження, тобто людей, здатних сприймати правди Його волі і давати плоди праведності” (Хомік/Хомік/Петрова 2019: Дерево; Райкен/Уилхойт/Лонгман 2005: Дерево). Для акцентуації семантики 'живодайність, плідність', вираженій словосполученням родить nлід, у цьому ж псалмі функціонують лексема-символ полова і словосполучення вітер 
розвіває з антонімічним значенням 'сухий, мертвий, безплідний’ („безбожні, вони як полова, що вітер її розвіває”, Пс 1:4).

Кількісна характеристика лексем на позначення людини, що живе в єдності з Богом, найчастіше представлена граматичною формою однини, на противагу формам множини лексем безбожні, вороги, беззаконники тощо як виразу антонімічного значення 'віддаленість від Бога' („Устань же, о Господи, в гніві Своїм, понесися на лютість моїх ворогів, і до мене скеруй постанову Свою”, Пс 7:7; „у тіні Своїх крил заховай Ти мене від безбожних”, Пс 16:8-9; „Відступіться від мене, усі беззаконники, бо почув Господь голос мого плачу!”, Пс 6:9). Граматична форма однини виражає семантику 'поодинокість, вибраність праведних', що знаходить підтвердження у тексті Нового Завіту „багато бо покликаних, але мало вибраних” (Мт 22:14).

Наступний фасетний елемент опису концепту ПРАВЕДНИЙ, наявного в текстах Псалтиря перекладу Івана Огієнка, - це основні атрибутиви, виражені як лексемами, словосполученнями, так і ширшими контекстами. Нами виявлено, що у початкових псалмах функціонують поодинокі атрибутиви та цілі семантичні моделі відповідно до значень, виокремлених у лексемі $п p a-$ ведний: а) 'ступінь єдності з Богом' + 'радісний' + 'невинний', б) ‘благословенний' + 'вислуханий' + 'винагороджений', в) 'безпечний, захищений Богом’, г) 'правдомовний, щирий', г) 'слабкий, стривожений' та кілька інших. Варто зазначити, що наведені нижче мовні засоби актуалізують позитивний оцінний компонент у номенах особи, яка перебуває в єдності з Богом.

а) Вербальна реалізація першого елемента вказаної домінантної моделі ‘ступінь єдності праведного з Богом’ здійснюється у такому тексті: „Блажен муж, що за радою несправедливих не ходить, і не стоїть на дорозі грішних, і не сидить на сидінні злоріків” (Пс 1:1). Задля розкриття семантики “ступінь єдності праведного з Богом' автор псалма використав протиставне значення 'міра близькості праведного з грішниками', виражене заперечними формами дієслів не ходить, не стоїть, не сидить, додатково вводячи семантику 'категорії грішників', виражену трьома лексемами несправедливі (непобожні, неблагочесні), грішні (які хиблять), злоріки (насмішники, циніки) (детальніше див. Тимо 2020). Тексти псалмів містять також вияви кореляції значень ‘єдність із Богом' і ‘вірність Богові’ та позитивний аксіологічний компонент. Їх експліцитно виражають стверджувальні та заперечні форми слів беріг, не відступив, не відкидав, стерігся („беріг я дороги Господні, і від Бога свого я не відступив [...] і не відкидав я від себе Його постанов! [...] і стерігся своєї провини”, Пс 17:22-24; „за словом уст Твоїх я стерігся доріг гнобителя”, Пс 16:4). Ці лексеми вказують на реалізацію першого значення лексеми праведний, зафіксоване у словниках української мови.

Як свідчать контексти аналізованих початкових псалмів, другий семантичний елемент моделі, 'радісний', прямо пов'язаний зі значенням 'єдність із Богом’ і вказує на наслідок такого тісного зв’язку. „Біблійна енциклопедія 
Брокгауза” (Рикерен/Майер 1999: Радость; веселье) вказує, що „справжня радість свідчить про повноту земного життя й участь у небесному щасті. [...] Щоби постійно відчувати радість, слід черпати $\dddot{11}$, „з джерел спасіння" (Ic 12:3; 35:10), шукати їі у Бога (Пс 42:4). Указане значення реалізують іменник радість (,радість велика з Тобою”, Пс 15:11), дієслова і дієслівні форми тіматься, будуть співати, будуть радіти („А всі, хто надію на Тебе складають, хай тішаться, будуть вічно співати вони, і Ти їх охорониш, і будуть радіти”, Пс 5:12) та предикативні конструкції серие радіє, дух веселиться („Він по правиці моїй [...], через те моє серце радіє та дух веселиться”, Пс 15:8-9).

Атрибутив 'невинний' указує на семантику 'чеснота, набута внаслідок випробуванних вимог до праведного' та високу оцінку аналізованого ментального предмета. У текстах це значення виражене експліцитно, за допомогою іменників правота, невинність („суди ж мене, Господи, за моєю правотою й за моєю невинністю”, Пс 7:9; „очі Твої нехай бачать мою правоту!”, Пс 16:2). У псалмах зафіксовано мовне вираження семантики 'чистий', яка корелює з процесом випробування та становить набуту чесноту праведного: „Про значення слова чистий можна стверджувати на основі грецького слова ейлікрінес, що складається з двох коренів: „солнце” і „випробовувати” („випробуваний сонцем” - Септуагінта і НЗ)” (Ринекер/Майер 1999: Чистота, нечистота; чистий, нечистий). Відтак, невинність праведного часто проявляється під час випробування й одночасно становить його нагороду: „Ти випробував моє серце, навістив уночі, перетопив Ти мене, й не знайшов чогось злого” (Пс 16:3), „суди ж мене, Господи, за моєю правотою й за моєю невинністю” (Пс 7:9), „Бо Господь справедливий, кохає Він правду, праведний бачить обличчя Його!” (Пс 10:7).

б) ‘Благословенний’ + ‘вислуханий’ + ‘винагороджений'. Як показав аналіз початкових текстів Псалтиря, ці поняття функціонують в тісному зв’язку. „Під благословенням Біблія розуміє звернення Божої любові, благодаті на людину" (Ринекер/Майер 1999: Благословення). Це значення експліцитно виражає дієслово благословлятимеш („Бо Ти, Господи, благословлятимеш праведного”, Пс 5:13). Відповідно до „Словника української мови”, однією зі сем у структурі лексеми благословенний є 'щасливий', що вказує на мисленнєву установку 'один із наслідків пізнання Бога' у тексті „Ти вчиниш його благословенням вічним, звеселиш його радістю, як буде він разом з Тобою!” (Пc 20:7).

Семантика 'благословенний' корелює в текстах зі значеннями 'вислуханий' i ‘винагороджений'. Значення 'благословення' імпліцитно містять тексти з семантичним компонентом 'вислухана молитва в храмі', що його імпліцитно реалізують словосполучення почує голос („В тісноті своїй кличу до Господа, і до Бога свого я взиваю, Він почує мій голос із храму Свого", Пс 17:7) і лексико-граматична конструкція доходить зойк в уші (,і доходить мій зойк до лиця Його в уші Йому!”, Пс 17:7). У біблійному контексті сло- 
во вислуханий пов’язане зі семантикою 'перебування в храмі', де юдеї могли наблизитися до Бога в молитві й принести жертву. Це значення експліцитно виражають дієслівні словосполучення перебувати в наметі Твоїм, мешкати на святій Твоїй горі (,хто може перебувати в наметі Твоїм? Хто мешкати може на святій Твоїй горі”, Пс 14:1), до дому Твого ввійду („А я в ласці великій Твоїй до дому Твого ввійду”, Пс 5:8). Відтак семантика “вислухана молитва в храмі’ містить одночасно високу оцінку праведного.

Щодо другого елемента 'винагороджений', то „благословення трактується [...] як нагорода за послух” (Райкен/Уилхойт/Лонгман 2005: Благословение). Таке значення, 'отримати винагороду за вірність єдиному Богові', імпліцитно виражають словосполучення з компонентом, який містить семантику 'отримати спадок’: частки припали, гарна спадщина (,Частки припали для мене в хороших місцях, і гарна для мене спадщина моя!’, Пс 15:6). Речення „Господь то частина спадку мого та чаші моєї” (Пс 15:5) виражає теологічно пізніше значення ‘одухотвореності спадку' (пор. Леон-Дюфур 1990: Наследствие).

в) Ознака ‘захищений/врятований Богом’ указує на семантику 'той, який заслужив на захист/рятунок від Бога перед нападниками’. Її імпліцитно виражають іменники, що містять семи 'давати захист/прихисток/допомогу в боротьбі’: щзит (,Щит мій у Бозі”, Пс 7:11), твердиня, притулок (,І твердинею буде Господь для пригніченого, в час недолі притулком”, Пс 9:10), скеля, башта („Мій Бог моя скеля, сховаюсь я в ній, Він щит мій [...], Він башта моя!”, Пс 17:2-3), а також дієслово підпирає („Господь підпирає мене, і я не побоюсь десяти тисяч люду”, Пс 3:6-7). Експліцитно семантику 'Божий порятунок від нападників’ реалізують дієслова врятував („Він мене врятував, бо вподобав мене”, Пс 17:20), cnacaє („Щит мій у Бозі, Який чистих серцем спасає”, Пс 7:11), не кинув (,не кинув Ти, Господи, тих, хто шукає Тебе!”, Пс 9:10-11), а також лексико-граматична конструкція Він по правиці моїй, й не буду захитаний! (Пс 15:8-9). Остання актуалізує позитивний оцінний компонент в семантичній структурі номенів праведного, оскільки права частина тіла корелює зі сакральною сферою, дотичністю до Бога (Райкен/Уилхойт/ Лонгман 2005: Правая сторона). Семантика 'врятований' у Біблії корелює також зі значенням 'врятований від посмертного забуття' та вказує на високу оцінку праведного, що виражають словосполучення не опустиш душі до шеолу, не попустиш побачити тління („Бо Ти не опустиш моєї душі до шеолу, не попустиш [...] побачити тління!", Пс 15:10).

г) Ознака ‘правдомовний, щирий’ відповідає другому з наведених вище словникових значень лексеми праведний і $є$ передумовою набуття статусу праведного. Ця семантика експліцитно виражена в текстах словосполученнями уста необлудні („Почуй молитву мою із уст необлудних!”, Пс 16:1), правду говорить, не обмовляє (,правду говорить у серці своїм, хто не обмовляє своїм язиком”, Пс 14:1-3). Ця ознака вказує також на семантику “любов до 
ближнього', 'дотримання слова', 'чесність', що виражено, відповідно, дієсловами присягає і дотримує (,присягає, для себе хоча б і на зло, і дотримує”, Пс 14:1-3); заперечними словосполученнями не дає срібла на лихву, не бере niдкyny (,не дає свого срібла на лихву, і не бере на невинного підкупу”, Пс 14:1-3) і ближнього не зневажає („,вого ближнього не зневажає”, Пс 14:1-3). Такі мовні характеристики містять безумовно високу і позитивну оцінку аналізованого предмета.

У перших двадцяти псалмах присутня й нечастотна ознака 'слабкий, стривожений', пов’язана з великою кількістю духовних і фізичних ворогів. Цю семантику експліцитно виражають прикметник слабий („Помилуй мене, Господи, я ж бо слабий”, Пс 6:3), дієслово змучився (,Змучився я від стогнання свого”, Пс 6:7) і предикативи око зів'яло, постаріло („Моє око зів’яло 3 печалі, постаріло через усіх ворогів моїх", Пс 6:8). Другу частину ознаки, 'стривожений', реалізують предикативи тремтять кості, душа стривожена (,уздоров мене, Господи, бо тремтять мої кості, і душа моя сильно стривожена”, Пс 6:3-4), а також речення „щоночі постелю свою обмиваю слізьми, сльозами своїми окроплюю ложе своє!" (Пс 6:7). Низька частотність мовних засобів вираження наведених атрибутивів у початкових текстах псалмів свідчить про те, що основним поняттям, яке знаходить вираження саме в цих текстах, є 'подяка за вчинені Богом добродійства' і 'прослава Бога'. У подальших дослідженнях теми варто буде прослідкувати розвиток і можливу трансформацію семантики 'слабкий, стривожений'.

У межах лінгвальних способів реалізації характеристики 'дії праведного' можна виокремити дві групи мовних засобів. Перша реалізує семантику 'дії праведного щодо Бога', друга ж - ‘дії праведного щодо грішників'.

Перша група, пов'язана зі загальним значенням 'основні дії праведного щодо Бога', містить два семантичні підвиди: а) 'дії з метою наближення до Бога', б) ‘безпосередній заклик Бога до покарання грішників’.

a) Перший семантичний підвид, 'дії з метою наближення до Бога', peaлізують мовні засоби з таким значенням:

- 'пізнає Бога', що експліцитно виражають дієслова роздумує, пізнав (,про Закон Його вдень та вночі він роздумує!”, Пс 1:2; „Тепер я пізнав, що спасає Господь помазанця Свого”, Пс 19:7);

- 'хвалить, благословляє Бога', експліцитно виражена дієслівними формами хвалю, благословляю, співаю, буду хвалити/виспівувати/ співати/ miuитись („хвалю Тебе, Господи, серед народів, і Йменню Твоєму співаю!”, Пс 17:50; „Благословляю я Господа”, Пс $15: 7 ;$,Я буду радіти, і тішитись буду Тобою, і буду виспівувати Ймення Твоє”, Пс 9:3; „Я ж Господа буду хвалити", Пс 7:18);

- 'надіється, опирається на Бога', експліцитно виражені дієсловами опирається („На Тебе слабий опирається”, Пс 9:35), надіюсь/надіятись будуть (,Я надіюсь на Господа”, Пс 10:1; „І на Тебе надіятись будуть усі, що Ім’я Твоє 
знають”, Пс 9:11), а також словосполученнями надію покладаю („Я надію на милість Твою покладаю”, Пс 12:6); має надію („Цар має надію на Господа”, Пс 20:8) і предикативом уявляю Господа постійно (,Уявляю я Господа перед собою постійно", Пс 15:8).

б) Другий семантичний підвид, 'безпосереднє закликання Бога до покарання грішників, виражають численні словосполучення з імперативами у 2 особі однини, які вказують на значення 'близькі стосунки праведного з Богом'. Також ці мовні засоби реалізують потрійну семантику, яка свідчить про одне з головних бажань праведного - встановлення справедливості, яка часто дорівнює помсті:

- 'прохання про справедливий суд’: признай за винних, відкинь від Себе, злого скарай („Признай їх за винних, о Боже, [...] за їхні великі злочинства відкинь їх від Себе”, Пс 5:11; „злого скарай за неправду його”, Пс 10:16).

- 'прохання до Бога показати свою помсту'. Це значення може бути виражене двояко. Перша група мовних засобів - це наказова форма дієслова в 2 особі однини: устань в гніві, понесися на лютість ворогів, накинь пострах, руку підійми, зламай рамено, нехай підітне уста та язика, кинь на коліна (,Устань же, о Господи, в гніві Своїм, понесися на лютість моїх ворогів”, Пс 7:7; „Накинь, Господи, пострах на них, нехай знають народи, що вони тільки люди!”, Пс 9:20-21; „Устань же, о Господи Боже, руку Свою підійми”, Пс 9:33; „Зламай же рамено безбожному”, Пс 10:16; „Нехай підітне Господь уста облесливі та язика чванькуватого”, Пс 11:4; „Устань же, о Господи, його попередь, кинь його на коліна!", Пс 16:13). Друга група мовних експлікацій імператив у 3 особі однини і множини: нехай злоба скінчиться, хай людина не перемагає, хай упадуть, хай схоплені будуть, нехай множаться смутки, нехай не панують („Нехай злоба безбожних скінчиться”, Пс 7:10, „хай людина не перемагає! [...] через свої заміри хай упадуть”, Пс 5:11; „хай схоплені будуть у підступах”, Пс 9:23; „Нехай множаться смутки для тих, хто набув собі інших богів”, Пс 15:4; „від свавільців Свого раба заховай, нехай не панують вони надо мною”, Пс 18:14).

- 'впевненість у Божій помсті', яку виражають дієслова в формі майбутнього часу 2 і 3 ос. однини повбиваєш/ потовчеш/ вигубиш/ спустить/ знайде/ понищить/ пожере (,Ти їх повбиваєш залізним жезлом, потовчеш їх, як посуд ганчарський”, Пс 2:8-9; „Ти вигубиш плід їхній із землі”, Пс 20:11; „Він спустить дощем на безбожних горюче вугілля, огонь, і сірку, і вітер гарячий”, Пс 10:6; „Знайде рука Твоя всіх ворогів Твоїх, знайде правиця Твоя Твоїх ненависників [...] Господь гнівом Своїм їх понищить”, Пс 20:9).

Друга група мовних засобів, які реалізують загальну семантику 'основна дія праведного щодо грішних', також корелюють зі значенням 'вчиняти помсту самому або в співдії з Богом'. Імпліцитно перша частина виражена дієсловами майбутнього часу в 1 ос. однини дожену, винищу, потрощу, зітру, nomonчy (,,ї дожену, і не вернуся, аж поки не винищу їх, я їх потрощу”, 
Пс 17:38-39; „,понищу ненависників я своїх! [...] I я їх зітру, як той порох на вітрі, як болото на вулицях, їх потопчу!”, Пс 17:41, 43). Друга ж частина виражена словосполученнями з Тобою побю, з Богом проберусь через мур (,Бо з Тобою поб'ю я ворожого відділа, і з Богом своїм проберусь через мур”, Пс 17:30).

Варто відзначити, що наведена кількість мовних засобів на позначення семантики 'бажання помсти’ вкрай типова для текстів Старого Завіту. „Біблійна енциклопедія Брокгауза” (Ринекер/Майер 1999: Месть;мстить) вказує, що „Бог не випадково названий Богом помсти (Єр. 51:6), оскільки „Він відімститься за кров Своїх всіх рабів, і пімсту поверне Своїм ворогам” (Втор. 32:41) [...] Тому зрозумілі звернені до Бога заклики про помсту. Так випробовуються люди, які не хочуть чекати, поки Бог здійснить відплату [...] можуть впасти у спокусу, молячись „Нехай в наших очах між народами стане відомою помста за пролиту кров Твоїх рабів” (Пс 78:10).

Концепт ПРАВЕДНИЙ становить один із ключових елементів, які співтворять мовний образ Бога в українському світі Книги Псалмів перекладу І. Огієнка. Спроба реконструкції деяких фрагментів концепту дозволила прослідкувати Огієнкові способи осмислення старозавітних категорій багатющими українськими мовними засобами. Їхній аналіз дав змогу виокремити в межах кожного з аспектів профілю ПРАВЕДНОГО (номени, атрибутиви, діiі) численні семантичні підвиди з їхнім обширним українським лексичним і лексико-граматичним наповненням, яке занурює читача в ментальний світ авторів Псалтиря, розкриваючи особливості юдейського світобачення. Подальші частини дослідження будуть присвячені грунтовному аналізові тих мовних засобів, які реалізують мисленнєву колекцію 'Бог - грішник', що стане наступним елементом у процесі реконструкції цілісного мовного образу Бога в старозавітних текстах блискучого перекладу Івана Огієнка.

\section{Використана література}

BARTMIŃSKi Jerzy, 1988, Definicja kognitywna jako narzędzie opisu konotacji, в: [v:] Bartmiński J. (ред. [red.]), Konotacja, Lublin, c. [s.] 169-183.

BARTMIŃSKi Jerzy, 1993, Profilowanie pojęć: wybór prac, Lublin.

BARTMIŃSKi Jerzy, 2006, Językowe podstawy obrazu świata, Lublin.

BARTMIŃSKi Jerzy, 2009, Aspects of Cognitive Ethnolinguistics, London.

BARTMIŃSKi Jerzy, 2016, O aktualnych zadaniach etnolingwistyki, B: [v:] Etnolingwistyka 28, c. [s.] 7-29.

BARTMIŃSKi Jerzy / Chlebda Wojciech, 2013, Problem konceptu bazowego i jego profilowania - na przykładzie polskiego stereotypu Europy, в: [v:] Etnolingwistyka 25, c. [s.] 69-95.

BARTMiŃSKi Jerzy / NiebrzegowsKa Stanisława, 1998, Profile a podmiotowa interpretacja świata, в: [v:] Bartmiński J./Tokarski R. (ред. [red.]), Profilowanie w języku i w tekście, Lublin, c. [s.] 211-224. 
BoAs Franz / Powell John Wesley / Holder Preston, 1966, Introduction to the Handbook of American Indian Languages, Lincoln.

Humbold Wilhelm von, 1999, On Language: On the Diversity of Human Language Construction and its Influence on the Mental Development of the Human Spieces, Cambridge.

Niebrzegowska-Bartmińska Stanisława, 2015, O profilowaniu językowego obrazu świata, B: [v:] Poradnik Językowy 1, c. [s.] 30-44.

Білодід Костянтин (ред.), 1976, Словник українськоїмови, т. 7, http://sum.in.ua/s/pravednyj (доступ: 23.01.2021) [Bilodid Kostyantyn (red.), 1976, Slovnyk ukrayins'koyi movy, t. 7, http://sum.in.ua/s/pravednyj (dostup: 23.01.2021)].

Грінченко Борис (ред.), 1958, Словарь української мови, т. 3, http://ukrlit.org/slovnyk/ hrinchenko_slovar_ukrainskoi_movy/праведний (доступ: 23.01.2021) [Hrinchenko Borys (red.), 1958, Slovar' ukrayins'koyi movy, t. 3, http://ukrlit.org/slovnyk/hrinchenko_slovar_ ukrainskoi_movy/праведний (dostup: 23.01.2021)].

Дзера Оксана, 2014, Історія українських перекладів Святого Письма, в: Іноземна філологія 127 (Ч. 2), c. 214-222 [Dzera Oksana, 2014, Istoriya ukrayins'kykh perekladiv Svyatoho Pys'ma, v: Inozemna filolohiya 127 (Ch. 2), s. 214-222].

Срмоленко Світлана, 1999, Нариси з української словесності: стилістика і культура мови, Київ [Yermolenko Svitlana, 1999, Narysy z ukrayins'koyi slovesnosti: stylistyka i kul'tura movy, Kyyiv].

Іларіон митрополит, 1958, Біблія - найперше джерело для вивчення своєї літературної мови, в: Bipa і культура 6 (66), с. 13-17 [Ilarion mytropolyt, 1958, Bibliya - naypershe dzherelo dlya vyvchennya svoyeyi literaturnoyi movy, v: Vira i kul'tura 6 (66), s. 13-17].

Кісь Роман, 2002, Мова, думка і культурна реальність (від Олександра Потебні до гіпотези мовного релятивізму), Львів [Kis' Roman, 2002, Mova, dumka i kul'turna real'nist' (vid Oleksandra Potebni do hipotezy movnoho relyatyvizmu), L'viv].

Книга Псалмів, 2009, http://www.my-bible.info/biblio/ukrainskaya-bibliya/psalmy.html (доступ: 20.01.2021) [Knyha Psalmiv, 2009, http://www.my-bible.info/biblio/ukrainskaya-bibliya/ psalmy.html (dostup: 20.01.2021)].

Леон-Дюфур Ксавье (ред.), 1990, Словарь библейского богословия, http://yakov.works/ spravki/4_faith_bible/slovari/1970_dufur_00.html (доступ: 23.01.2021) [Leon-Dyufur Ksav'ye (red.), 1990, Slovar' bibleyskogo bogosloviya, http://yakov.works/spravki/4_faith_ bible/slovari/1970_dufur_00.html (dostup: 23.01.2021)].

Мельничук Олександр (ред.), 2003, Етимологічний словник української мови, т. 4, https:// archive.org/details/etslukrmov4/page/n549/mode/2up?q=праведний (доступ: 28.01.2021) [Mel'nychuk Oleksandr (red.), 2003, Etymolohichnyy slovnyk ukrayins'koyi movy, t. 4, https:// archive.org/details/etslukrmov4/page/n549/mode/2up?q=праведний (dostup: 28.01.2021)].

Райкен Лилойд / Уилхойт Джеймс / Лонгман Тремпер (ред.), 2005, Словарь библейских обра-зов, https://azbyka.ru/otechnik/Spravochniki/slovar-biblejskih-obrazov/548 (доступ: 25.01.2021) [Rayken Liloyd / Uilkhoyt Dzheyms / Longman Tremper (red.), 2005, Slovar' bibleyskikh obrazov, https://azbyka.ru/otechnik/Spravochniki/slovar-biblejskih-obrazov/548 (dostup: 25.01.2021)].

Ринекер Фритц/Майер Герхард, 1999, Библейская энциклопедия Брокгауза, https://bible. by/lexicon/brockhaus/word/2478/ (доступ: 20.02.2021) [Rineker Fritts / Mayyer Gerkhard, 1999, Bibleyskaya entsiklopediya Brokgauza, https://bible.by/lexicon/brockhaus/word/2478/ (dostup: 20.02.2021)].

„Словники України” online, https://lcorp.ulif.org.ua/dictua/ (доступ: 23.01.2021) [„,Slovnyky Ukrayiny" online, https://lcorp.ulif.org.ua/dictua/ (dostup: 23.01.2021)].

Тимо Тарас, 2020, Псалом 1 - частина 1, частина 2, https:/www.youtube.com/watch?v=eNeffl T6jks; https://www.youtube.com/watch?v=9QHCcK87q1g, (доступ: 10.01.2021) [Tymo Taras, 
2020, Psalom 1 - chastyna 1, chastyna 2, https://www.youtube.com/watch?v=eNefflT6jks; https://www.youtube.com/watch?v=9QHCcK87q1g (dostup: 10.01.2021)].

Хомік Володимир / Хомік Андрій / Петрова Світлана (ред.), 2019, Словарь духовно-образ-ного значения слов и изречений Библии, https://bibleword.inf.ua/slovar/d/40-derevo.html (доступ: 29.01.2021) [Khomik Volodymyr / Khomik Andriy / Petrova Svitlana (red.), 2019, Slovar' dukhovno-obraznogo znacheniya slov i izrecheniy Biblii, https://bibleword.inf.ua/ slovar/d/40-derevo.html (dostup: 29.01.2021)].

\section{Sketches of the linguistic image of the RIGHTEOUS in the Ukrainian texts of the Psalter (translated by Ivan Ohienko)}

This article is a part of a study on the integral linguistic image of God in the Ukrainian translation of the Psalter translated by Ivan Ohienko. The important role of Ohienko's texts comes from the scientific nature of the translation and the influences in the formation of literary language. The author of the study is interested in the ways and means by which the concept of the RIGHTEOUS one of the most frequent elements God functions with in text collections - is verbally expressed. Therefore, in this study, attention is focused on an attempt to ethnolinguistically analyse (based on the conception of profiling by J. Bartmiński) of the Ukrainian lingual implementation of such biblical concepts as 'righteous person', 'the main signs of a righteous person associated with God', and 'the actions of a righteous person towards a) God, b) sinners'. As a result, it will be possible to trace the richness and diversity of the language image 'righteous' created by Ivan Ohienko, by bringing readers closer to the understanding of the ways of linguistic filling of in Old Testament texts with Ukrainian language means.

Keywords: linguistic model, concept, attribute, semantics. 